\title{
FAKTOR - FAKTOR YANG MEMPENGARUHI JUMLAH PENDAFTAR SMA/MA DI KABUPATEN SUMENEP MENGGUNAKAN ANALISIS REGRESI VARIABEL DUMMY
}

\author{
Anik Anekawati \\ Prodi Pendidikan IPA FKIP Universitas Wiraraja
}

\begin{abstract}
ABSTRAK
Penelitian ini bertujuan untuk mengetahui faktor apa saja yang mempengaruhi jumlah pendaftar sekolah SMA/MA di Kabupaten Sumenep, mendeskripsikan secara kuantitatif jumlah sekolah dan pendaftar SMA/MA di Kabupaten Sumenep berdasarkan mutu sekolah dan lokasi, mengkaji gejala disparitas pendidikan dalam kesempatan memperoleh pendidikan yang bermutu tingkat SMA/MA di Kabupaten Sumenep. Variabel independen adalah akreditasi, status sekolah, jenis sekolah, status mutu dan lokasi sekolah. Variabel dependen adalah jumlah pendaftar. Jumlah sampel 102 sekolah. Analisis data menggunakan analisis regresi variabel dummy dan uji beda kruskall-wallis. Hasil analisis regresi dummy didapatkan, yang berpengaruh terhadap jumlah pendaftar adalah status sekolah dan akreditasi. Jumlah pendaftar sekolah dengan status negeri 91,1\% lebih banyak dari pada sekolah dengan status swasta. Jumlah pendaftar Sekolah dengan akreditasi A $161 \%$ kali lebih banyak dibandingkan sekolah yang belum terakreditasi. Sekolah dengan akreditasi B lebih diminati 86,2\% kali dibandingkan sekolah yang tidak terakreditasi. Hasil dari uji kruskall-wallis setidaknya terdapat 2 sekolah yang mempunyai rata-rata jumlah pendaftar yang berbeda. Urutan rata-rata jumlah pendaftar mulai tertinggi adalah sekolah negeri akreditasi A, negeri akreditasi B, swasta akreditasi A, swasta akreditasi B, swasta akreditasi $C$ dan swasta tidak terakreditasi. Dari hasil diskripsi disimpulkan terdapat gejala disparitas kesempatan dalam memperoleh pendidikan yang bermutu dan terdapat disparitas memperoleh kesempatan pendidikan yang tidak sama diantara berbagai tempat kota, pinggiran dan pesisir.
\end{abstract}

Kata kunci : regresi variabel dummy, uji kruskal-wallis, akreditasi, disparitas pendidikan

\section{PENDAHULUAN}

Secara geografis wilayah Kabupaten Sumenep terdiri dari daratan dan kepulauan dengan luas keseluruhan 2.093,46 Km², meliputi: (a). Bagian Daratan dengan luas 1.146,93 $\mathrm{Km}^{2}$ $(54,79 \%)$, dan (b). Bagian Kepulauan dengan luas 946,53 $\mathrm{Km}^{2} \quad(45,21 \%)$, dimana memiliki 126 pulau, 48 pulau berpenghuni dan 78 pulau tidak berpenghuni (BPS Kab. Sumenep, 2011). Secara administratif, Kabupaten Sumenep dibagi atas 27 kecamatan. Pola sosiodemografis yang terpisah tersebut menyebabkan setiap kecamatan dan setiap daerah di Kabupaten Sumenep mempunyai karakteristik wilayah unik yang berpotensi menimbulkan kesenjangan ekonomi, sosial, dan pendidikan (Santrock, 2010), antara daerah perkotaan, pinggiran, pesisir, dan kepulauan.

Pendidikan berhubungan dengan transformasi budaya, peradaban serta kualitas hidup sebuah bangsa. Mengacu standar UNDP (United Nations Development Programe), salah satu aspek penting menentukan indeks kualitas hidup adalah sektor pendidikan, yang diukur dari angka melek huruf dan rata-rata lama sekolah. Data BPS Kabupaten Sumenep (2011) menunjukkan bahwa angka partisipasi kasar SMA/MA 31,49\%, angka melek huruf $79,94 \%$, dan rata-rata lama sekolah 5,68 tahun. Data tersebut menunjukkan kesadaran diri masyarakat Sumenep akan pentingnya pendidikan 
sebagai alat untuk meningkatkan kualitas hidup masih rendah.

Sebenarnya, peran serta warga Sumenep dalam perencanaan dan pelaksanaan pengembangan pendidikan yang dikelola secara swadaya cukup baik. Data Dinas Pendidikan Sumenep (BPS Kab. Sumenep, 2011) menunjukkan 125 sekolah SMA/MA swasta (dikelola secara swadaya), sementara sekolah negeri hanya 12 sekolah. Namun demikian, banyaknya sekolah swadaya tersebut belum diimbangi dengan kelayakan mutu satuan pendidikan yaitu mencapai $72 \%$. Tingginya jumlah sekolah SMA/MA yang kurang bermutu tersebut berakibat tidak mampu memberi kesempatan yang memadai bagi siswanya untuk belajar yang efektif (Santrock, 2010).

Sementara itu, pola etnis yang tradisional-agamis juga menentukan motivasi dalam menggapai cita-citanya (Hudgins, 1983). Penentuan dalam memilih sekolah cenderung kolektif (Santrock, 2010; Hudgins, 1983), yaitu mengikuti teman dan kerabat dekat serta berbasis Islam tanpa memperhatikan mutu sekolah. Munculnya pembagian wilayah kerja (informal) antara pria dan wanita sangat dramatis (Santrock, 2010), dimana pria disosialisasikan dan disekolahkan untuk mencari nafkah dan bekerja di ruang publik, sementara wanita disosialisasikan untuk tetap di rumah tangga dan mengasuh anak (Santrock, 2010). Artinya, masyarakat Sumenep lebih banyak memberi kesempatan dan opsi kepada (anak) pria untuk bersekolah daripada (anak) wanita.

Sekolah adalah sebuah tempat yang menyelenggarakan proses pendidikan, yang memberdayakan segala input sehingga mampu menghasilkan output dan outcome yang berkualitas. Mutu sebuah lembaga pendidikan akan menyediakan layanan pendidikan kepada siswa lebih efektif. Dengan layanan yang baik akan mempengaruhi sosioemosional (Santrock, 2010; Hudgins, 1983), kognitif serta fisik mereka. Untuk menjamin terselenggaranya proses pendidikan yang bermutu, bermakna, menyenangkan, mencerdaskan serta lulusan berkualitas maka diperlukan standarisasi lembaga pendidikan yaitu kriteria minimal tentang sistem pendidikan di seluruh wilayah hukum Negara Kesatuan Republik Indonesia yang dinyatakan dalam terakreditasi.

Akreditasi adalah pengakuan standar kelayakan program dan/atau satuan pendidikan berdasarkan kriteria yang telah ditetapkan (Undang Undang RI No, 20 tahun 2003) yang dilakukan oleh lembaga independen (diberi kewenangan oleh pemerintah) menggunakan instrumen dan kriteria yang mengacu pada Standar Nasional Pendidikan/SNP (Peraturan Pemerintah RI No. 19 tahun 2005). SNP tersebut merupakan dijadikan acuan minimal dalam pengembangan dan pengendalian lembaga pendidikan meliputi: (1) standar isi kurikulum, (2) standar kompetensi lulusan, (3) standar penilaian, (4) standar sarana-prasarana, (5) standar proses pembelajaran, (6) standar tenaga kependidikan, (7) standar pengelolaan, (8) standar pembeayaan.

Untuk tingkat Sekolah Menengah (SMA/MA), penilaian dan penetapan standar akreditasi atau kelayakan tersebut dilakukan oleh BASNAS atau BAN S/M (Badan Akreditasi Nasional Sekolah Menengah) yang dibantu oleh Badan Akreditasi Propinsi yang dibentuk Gubernur (Peraturan Pemerintah RI. No. 19 Tahun 2005). Hasilnya adalah diwujudkan dalam bentuk pengakuan peringkat mencerminkan kinerja sekolah serta jaminan bahwa sekolah tersebut dapat memberikan layanan yang baik dan memenuhi standar secara nasional, sehingga akan memberikan layanan pembelajaran yang efektif (Santrock, 2010). 
Tabel 1. Klasifikasi Akreditasi

\begin{tabular}{|c|c|c|c|}
\hline No & Klasifikasi Akreditasi & Nilai & Keterangan \\
\hline 1 & A & 86 s.d. 100 & Sangat baik \\
\hline 2 & B & 71 s.d. 85 & Baik \\
\hline 3 & C & 56 s.d. 70 & Cukup \\
\hline 4 & Tidak terakreditasi & 0 s.d. 55 & Tidak layak \\
\hline
\end{tabular}

Dalam rangka memudahkan masyarakat (atau bahkan sekolah) dalam memahami bagaimana wujud sekolah yang telah memenuhi kriteria SNP, Direktorat Pembinaan Sekolah Menengah Direktorat Jenderal Manajemen Pendidikan Dasar dan Menengah Depdikbud (sekarang Kemendiknas) serta dalam rangka proyek pembinaan peningkatan mutu sekolah merilis contoh nyata (Depdiknas, 2008) klasifikasi mutu sekolah, terdiri dari: (1)
SPM/SFS (Sekolah Potensial Mandiri/Sekolah Formal Standar), (2) SSN/SFM (Sekolah Standar Nasional/Sekolah Formal Mandiri), dan (3) RSBI (Rintisan Sekolah Bertaraf Internasional). Sekolah-sekolah tersebut di atas diharapkan dapat menjadi rujukan (bench mark) sekolah lain yang statusnya berada di bawahnya sehingga terpacu untuk meningkatkan dirinya menjadi sekolah yang baik dan mandiri.

Tabel 2.Klasifikasi Mutu Sekolah

\begin{tabular}{|c|c|c|}
\hline SPM/SFS & SSN/SFM & RSBI \\
\hline $\begin{array}{l}\text { - } \text { Sekolah Negeri/Swasta } \\
\text { - } \text { Memiliki rata-rata nilai } \\
\text { UAN di bawah SSN } \\
\text { - Sekolah Swasta yang } \\
\text { dikelola yayasan } \\
\text { dengan pendanaan } \\
\text { kurang } \\
\text { - } \text { Nilai kriteria sekolah } \\
\text { di bawah nilai kriteria } \\
\text { SSN } \\
\text { - Profil di bawah kriteria } \\
\text { SSN }\end{array}$ & $\begin{array}{ll}\text { - } & \text { Sekolah Negeri/Swasta } \\
\text { - } & \text { Sekolah Swasta yang } \\
\text { memiliki pendanaan baik } \\
\text { - } & \text { Luas tanah minimal } \\
& 4000 \mathrm{~m}^{2} \\
\text { - } & \text { Jumlah rombel minimal } 9 \\
\text { dan maksimal } 27 \\
\text { - } & \text { Nilai rata-rata UN } \\
\text { minimal 6,35 } \\
\text { - } \\
\text { Nilai kinerja sekolah } \\
\text { minimal cukup } \\
\text { - Profil sekolah mendekati } \\
\text { atau memenuhi } 8 \text { aspek } \\
\text { SNP }\end{array}$ & 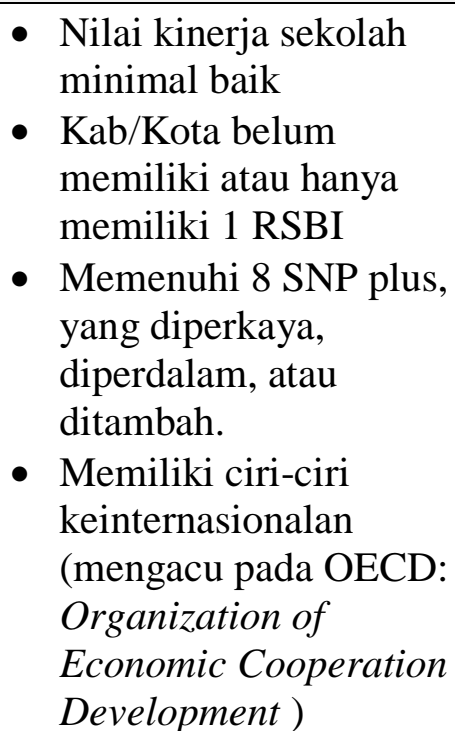 \\
\hline
\end{tabular}

Disamping pertimbangan kondisi internal sekolah (status sekolah, status mutu, akreditasi, dll), pola sosial dalam menentukan dan memilih sekolah yang bermutu sangat menentukan dalam pengembangan mutu lulusan. Kultur masyarakat Sumenep pedesaan dan pesisir yang tradisional akan cenderung memilih sekolah secara kolektif (Santrock,2010) atau berkelompok daripada daerah perkotaan yang cenderung independen. Sementara itu, pada tingkat sosioekonomi (ekonomi, individu, dan pekerjaan) yang rendah akan cenderung kurang kuat mempengaruhi institusi masyarakat/sekolah serta pendidikan (Santrock, 2010). Kultur masyarakat sumenep yang agamis, 99,8\% beragama Islam (BPS Kab. Sumenep: 2006) dan memegang kuat tradisi lokal mempengaruhi klasifikasi peran gender yang sangat dramatis (Santrock, 2010), dimana stereotipe pria adalah disekolahkan untuk bekerja di ruang publik, sementara wanita adalah tetap di dunia rumah tangga dan mengasuh anak. 
Berdasarkan paparan di atas, diperlukan penelitian tentang "Faktorfaktor yang Mempengaruhi Jumlah Pendaftar SMA/MA di Kabupaten Sumenep Menggunakan Analisis Regresi Variabel Dummy," yang bertujuan untuk: (1). mengetahui faktor apa saja yang mempengaruhi jumlah pendaftar sekolah SMA/MA di Kabupaten Sumenep; (2). mendeskripsikan secara kuantitatif jumlah sekolah dan pendaftar SMA/MA di Kabupaten Sumenep berdasarkan mutu sekolah dan lokasi; (3). mengkaji gejala disparitas pendidikan dalam kesempatan memperoleh pendidikan yang bermutu tingkat SMA/MA di Kabupaten Sumenep

Pemilihan SMA/MA karena mereka berada pada tahap mulai mandiri dan membuat keputusan sendiri (Santrock, 2010) dalam hidupnya, serta sebagai tolak ukur peluang untuk mendapatkan pekerjaan dan kualitas hidup lebih baik.

METODE

Populasi dalam penelitian ini adalah seluruh sekolah SMA dan MA di Kabupaten Sumenep sebanyak 137 sekolah. Teknik sampling yang digunakan adalah Metode Probability Sampling yaitu Metode Proposional Sampling Cluster dimana cluster didasarkan pada jenis dan status sekolah. Metode ini dipilih karena diduga terdapat homogenitas karakteristik sekolah-sekolah yang mempunyai jenis dan status sama dan sebaliknya mempunyai heterogenitas karakteristik sekolah-sekolah yang mempunyai jenis dan status yang berbeda. Sehingga diharapkan dapat memberikan sampel yang representatif. Jumlah sampel ditentukan dengan ukuran sampel diperoleh dengan menggunakan formula Yamane :

$$
n=\frac{N}{1+N B^{2}}
$$

Dengan $\mathrm{N}=$ populasi, $\mathrm{B}=$ batas kekeliruan sampling yang besarnya ditentukan oleh peneliti, yaitu 5\%. Dari persamaan (1) maka dapat dihitung jumlah sampel sebagai berikut :

$$
n=\frac{137}{1+137(0.05)^{2}} \quad=102 \text { sekolah }
$$

Tabel 3. Penentuan Sampel Secara Proposional.

\begin{tabular}{|c|c|c|c|}
\hline \multicolumn{3}{|c|}{ Populasi } & Sampel \\
\hline Jenis Sekolah & Status Sekolah & Jumlah Sekolah & Jumlah Sekolah \\
\hline SMA & Negeri & 11 & 8 \\
\hline SMA & Swasta & 31 & 23 \\
\hline MA & Negeri & 1 & 1 \\
\hline MA & Swasta & 94 & 70 \\
\hline \multicolumn{2}{|c|}{ Jumlah } & 137 & 102 \\
\hline
\end{tabular}

Selanjutnya sampel dipilih secara acak dari masing-masing kluster menggunakan bantuan software Minitab 14.

Variabel-variabel dalam penelitian ini adalah 1 variabel dependen dengan data metrik dan 5 variabel independen dengan data kategori diurai pada tabel 4 .. Data yang digunakan adalah data sekunder rangkuman data pendidikan SMA/MA dari Dinas Pendidikan Sumenep tahun pelajaran 2010-2011.

Tabel 4. Variabel Penelitian.

\begin{tabular}{|c|l|l|l|l|l|}
\hline $\begin{array}{l}\text { Variabel } \\
\text { Independen }\end{array}$ & \multicolumn{1}{|c|}{ Akreditasi } & $\begin{array}{c}\text { Status } \\
\text { Sekolah }\end{array}$ & Jenis Sekolah & $\begin{array}{c}\text { Status } \\
\text { Mutu }\end{array}$ & $\begin{array}{c}\text { Lokasi } \\
\text { Sekolah }\end{array}$ \\
\hline \multirow{2}{*}{ Kategori } & Akreditasi A & Negeri & SMA (umum) & SPM & Kota \\
\cline { 2 - 6 } & Akreditasi B & Swasta & MA (Agama) & PraSSN & Pinggiran \\
\hline
\end{tabular}




\begin{tabular}{|l|l|l|l|l|l|}
\hline \multirow{2}{*}{} & Akreditasi C & & & SSN & Pesisir \\
\cline { 2 - 6 } & Tidak Terakreditasi & & & RSBI & \\
\cline { 2 - 6 } & & & & SBI & \\
\hline Base Level & Tidak Terakreditasi & Swasta & MA (Agama) & SBI & Kota \\
\hline $\begin{array}{l}\text { Jumlah } \\
\text { Variabel } \\
\text { Dummy }\end{array}$ & 3 (tiga) & 1 (satu) & 1 (satu) & 4 (empat) & 2 (dua) \\
\hline $\begin{array}{l}\text { Variabel } \\
\text { Dependen }\end{array}$ & Jumlah Pendaftar SMA/MA & & & \\
\hline
\end{tabular}

Tahapan penelitian dan analisis

data pada penelitian ini adalah sebagai

berikut :

1. Uji Asumsi klasik

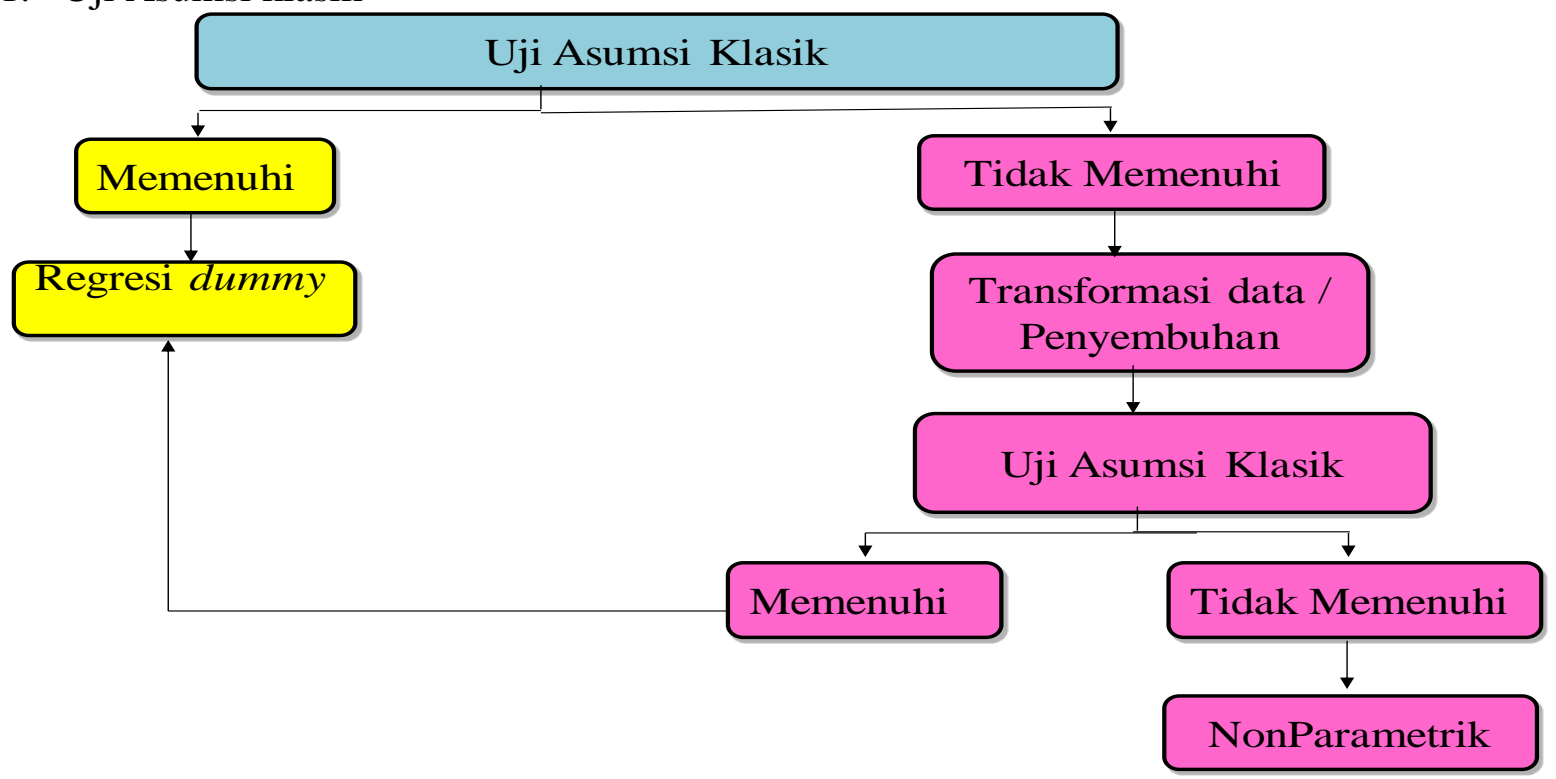

\section{a). Uji Normalitas Residual}

Menguji asumsi kenormalan residual menggunakan uji KolmogorovSmirnov, dengan hipotesisnya

$\mathrm{H}_{0}$ : residual berdistribusi normal

$\mathrm{H}_{1}$ : residual tidak berdistribusi normal

Jika p-value lebih dari 0,05 $(\alpha=5 \%)$ maka terima $\mathrm{H}_{0}$

b). Heteroskedastisitas

Gejala heteroskedastisitas

dideteksi dengan melakukan regresi fungsi-fungsi residual sebagai berikut :

$$
\left|\hat{e}_{i}\right|=\beta_{0}+\beta_{1} X_{1 i}+\beta_{2} X_{2 i}+v_{i}
$$

Jika variabel independen secara statistik signifikan melalui uji t maka ada masalah heteroskedastisitas

\section{c). Autokorelasi}

Uji independen ini dapat dilakukan dengan uji Durbin-Watson $d=\sum_{t=2}^{n} \frac{\left(e_{t}-e_{t-1}\right)^{2}}{\sum_{t=1}^{n} e_{t}^{2}}$ dengan hipotesis

$\mathrm{H}_{0}$ : tidak terjadi autokorelasi $\mathrm{H}_{1}$ : terjadi autokorelasi

Dasar pengambilan keputusan menurut Ghozali (2006:100) pada tabel berikut.

Tabel 5. Nilai Durban-Watson

\begin{tabular}{|l|c|c|}
\hline No & Nilai DW & Interpretasi \\
\hline 1 & $4-\mathrm{dl}<\mathrm{DW}<4$ & Ada autokorelasi (negative) \\
\hline
\end{tabular}




\begin{tabular}{|l|l|l|}
\hline 2 & $4-\mathrm{du}<\mathrm{DW}<4-\mathrm{dl}$ & Hasil tidak bisa ditentukan \\
\hline 3 & $\mathrm{du}<\mathrm{DW}<4-\mathrm{du}$ & Tidak ada autokorelasi \\
\hline 4 & $2<\mathrm{DW}<4-\mathrm{du}$ & Tidak ada autokorelasi \\
\hline 5 & $\mathrm{~d} l<\mathrm{DW}<\mathrm{du}$ & Hasil tidak bisa ditentukan \\
\hline 6 & $0<\mathrm{DW}<\mathrm{dl}$ & Ada autokorelasi \\
\hline
\end{tabular}

\section{d). Multikolinieritas}

Identifikasi secara statistik ada atau tidaknya gejala multikolinier dapat dilakukan dengan menghitung Variance Inflation Factor (VIF). Ghozali (2006: 96), untuk menunjukkan adanya multikolinier adalah nilai tolerance $\leq 0,1$ atau $\mathrm{VIF} \geq 10$

2. Uji model regresi dummy

\section{a). Uji F}

Untuk mengetahui ada tidaknya pengaruh secara simultan antara variabel independen kategorik terhadap variabel dependen, maka dilakukan pengujian dengan hipotesis sebagai berikut:

$\mathrm{H}_{0}: \beta_{1}=\beta_{2}=\beta_{3}=\beta_{4}=0$

$\mathrm{H}_{1}$ : minimal ada satu $\beta_{\mathrm{i}} \neq 0$ dengan $\mathrm{i}=1,2 . .4$

Kriteria penerimaan atau penolakan hipotesis jika $p$-value $<0,05$, maka tolak $\mathrm{H}_{0}$ atau jika $p$-value $>0,05$, maka terima $\mathrm{H}_{0}$

\section{b). Uji t}

Untuk mengetahui ada tidaknya pengaruh secara parsial antara masingmasing variabel independ terhadap jumlah pendaftar, maka dilakukan uji t dengan hipotesis sebagai berikut :

$\mathrm{H}_{0}$ : $\beta_{\mathrm{i}}=0$ (artinya variabel ke-i tidak berpengaruh secara nyata terhadap jumlah pendaftar dengan menganggap variabel lain konstan).

$\mathrm{H}_{1} \quad: \quad \beta_{\mathrm{i}} \neq 0 \quad$ (artinya variabel ke-i berpengaruh secara nyata terhadap jumlah pendaftar dengan
menganggap variabel lain
konstan). dengan $\mathrm{i}=1,2,3,4$.
Dalam penelitian ini digunakan tingkat signifikansi atau $\alpha=5 \%$ untuk uji dua sisi dengan kriteria penerimaan atau penolakan hipotesis : jika $p$-value $<0,05$, maka tolak $\mathrm{H}_{0}$ atau jika $p$-value $>0,05$, maka terima $\mathrm{H}_{0}$

3. Pemilihan model regresi dummy terbaik

Menggunakan anova dan uji $t$ untuk memilih variabel yang signifikan. Membuat beberapa model dengan cara memasukkan variabel yang signifikan satu per satu. Membandingkan beberapa model dengan melihat nilai $R^{2}$ dan adjusted $R^{2}$. Nilai $\mathrm{R}^{2}$ digunakan untuk mengukur seberapa baik garis regresi sesuai dengan data aktual (good of fit) atau mengukur total variasi dari variabel dependen yang dapat dijelaskan oleh variabel independen dalam model. Nilai $\mathrm{R}^{2}$ adjusted merupakan nilai $\mathrm{R}^{2}$ terkoreksi oleh banyaknya variabel yang masuk ke dalam model. Dipilih model terbaik dengan melihat nilai $\mathrm{R}^{2}$ yang tinggi dan nilai $\mathrm{R}^{2}$ adjusted yang mengalami peningkatan dari model sebelumnya.

4. Uji anova one way dan kruskall-wallis Untuk mengetahui adakah perbedaan rata-rata jumlah pendaftar dan untuk menentukan urutan yang paling diminati antara kombinasi kelompok yang signifikan, diuji menggunakan uji anova one way atau kruskall-wallis

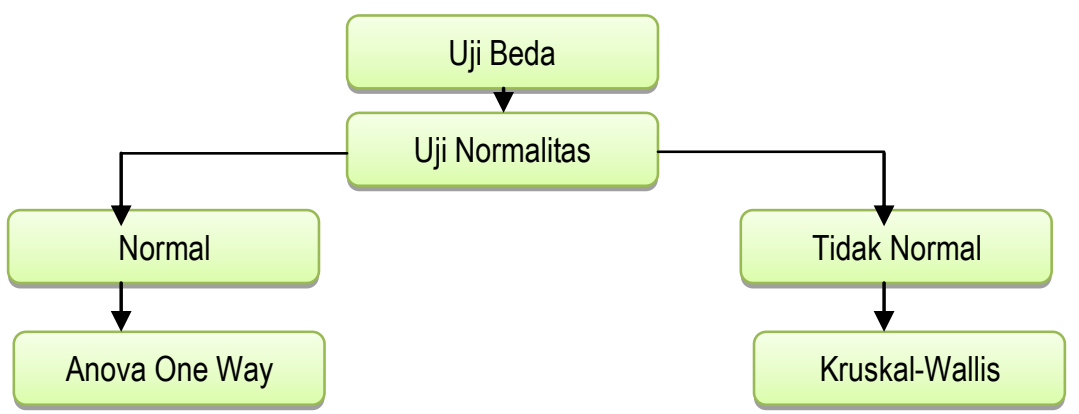


5. Analisis Crosstabing

Melakukan eksplorasi informasi melalui crosstabing data dari variabel yang berpengaruh terhadap jumlah pendaftar yang dihubungkan dengan lokasi sekolah untuk mengkaji gejala disparitas pendidikan sekolah tingkat SMA/MA di Kabupaten Sumenep
HASIL

\section{Statistika Deskriptif Karakteristik Sampel}

Karakteristik sampel dapat diketahui melalui analisis deskriptif berdasarkan data yang diperoleh adalah sebagai berikut

Tabel 6. Deskripsi Sekolah Berdasarkan Akreditasi

\begin{tabular}{|c|c|c|c|c|c|c|}
\hline \multirow[b]{2}{*}{ Jenis } & \multirow[b]{2}{*}{ Status } & \multicolumn{4}{|c|}{ Akreditasi } & \multirow[b]{2}{*}{ Jumlah } \\
\hline & & $\begin{array}{c}\text { Akreditasi } \\
\text { A }\end{array}$ & $\begin{array}{c}\text { Akreditasi } \\
\text { B }\end{array}$ & $\begin{array}{c}\text { Akreditasi } \\
\text { C }\end{array}$ & $\begin{array}{c}\text { Tidak } \\
\text { Terakreditasi }\end{array}$ & \\
\hline \multirow{2}{*}{ SMA } & Negeri & 4 & 4 & 0 & 0 & 8 \\
\hline & Swasta & 2 & 14 & 4 & 3 & 23 \\
\hline \multirow{2}{*}{ MA } & Negeri & 1 & 0 & 0 & 0 & 1 \\
\hline & Swasta & 3 & 10 & 30 & 27 & 70 \\
\hline \multicolumn{2}{|l|}{ Jumlah } & 10 & 28 & 34 & 30 & 102 \\
\hline
\end{tabular}

Gambaran sekolah menengah atas di Kabupaten Sumenep menurut status akreditasi adalah sebagai berikut : (1). semua SMA negeri terakreditasi dengan nilai A dan B, (2). SMA swasta terbanyak terakreditasi dengan nilai B yaitu $61 \%$ dan yang tidak terakreditasi $13 \%$, (3). MAN negeri terakreditasi dengan nilai A, (4). kondisi MA swasta yang mungkin agak kurang bagus dibanding yang lainnya, karena sebagian besar terakreditasi dengan nilai C sebanyak $43 \%$ dan belum terakreditasi sebanyak $39 \%$

Tabel 7. Deskripsi Sekolah Berdasarkan Status Mutu

\begin{tabular}{|c|c|c|c|c|c|c|}
\hline \multirow{2}{*}{ Jenis } & \multirow{2}{*}{ Status } & \multicolumn{4}{|c|}{ Status Mutu } & \multirow{2}{*}{ Jumlah } \\
\hline & & SPM & Pra SSN & SSN & RSBI & \\
\hline \multirow{2}{*}{ SMA } & Negeri & 1 & 1 & 5 & 1 & 8 \\
\hline & Swasta & 17 & 2 & 4 & 0 & 23 \\
\hline \multirow{2}{*}{ MA } & Negeri & 1 & 0 & 0 & 0 & 1 \\
\hline & Swasta & 48 & 12 & 10 & 0 & 70 \\
\hline \multicolumn{2}{|l|}{ Jumlah } & 67 & 15 & 19 & 1 & 102 \\
\hline
\end{tabular}

Gambaran sekolah menengah atas di Kabupaten Sumenep menurut status mutu adalah sebagai berikut : (1). sebagian besar SMA Negeri pada status mutu SSN dan satu sekolah yang berstatus mutu RSBI, (2). sebagian besar SMA Swasta pada status mutu SPM, (3). MAN Negeri berstatus mutu SPM, (4). sebagian besar MA Swasta berstatus mutu SPM.

Tabel 8. Deskripsi Sekolah Berdasarkan Lokasi Sekolah

\begin{tabular}{|c|c|c|c|c|c|}
\hline \multirow{2}{*}{ Jenis } & \multirow{2}{*}{ Status } & \multicolumn{3}{|c|}{ Lokasi } & \multirow{2}{*}{ Jumlah } \\
\cline { 3 - 6 } & & Kota & Pinggiran & Pesisir & \\
\hline \multirow{2}{*}{ SMA } & Negeri & 2 & 3 & 3 & 8 \\
\cline { 2 - 6 } & Swasta & 4 & 14 & 5 & 23 \\
\hline \multirow{2}{*}{ MA } & Negeri & 1 & 0 & 0 & 1 \\
\hline
\end{tabular}




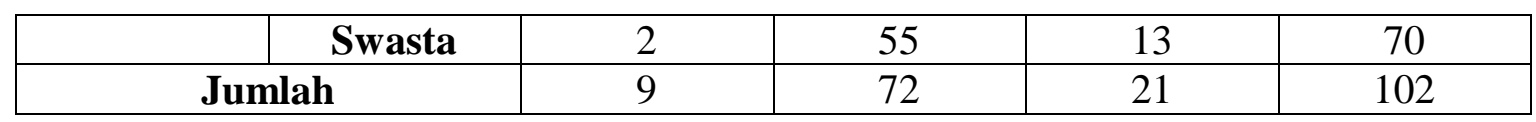

SMA negeri tersebar hampir merata di tiga lokasi kota, pinggiran dan pesisir. Sedangkan SMA swasta sebagian besar berada pada lokasi pinggiran. MA negeri berada di kota sedangkan MA swasta sebgaian besar berada pada lokasi pinggiran.

\section{Penentuan Model Regresi}

Uji normalitas terhadap residu model dilakukan sebelum dilakukan uji signifikansi variabel independen terhadap variabel dependen. Variabel independen dalam model adalah akreditasi, status sekolah, jenis sekolah, status mutu dan lokasi sekolah. Sedangkan variabel dependennya adalah jumlah pendaftar. Uji normalitas residu dari model menggunakan uji khai-square pada tingkat signifikansi $5 \%$ didapatkan nilai $\mathrm{P}_{\text {value }}$ kurang dari $5 \%$ yang berarti bahwa residu tidak terdistribusi normal. Hal ini berarti tidak memenuhi asumsi analisis regresi. Selanjutnya dilakukan transformasi data variabel jumlah pendaftar ke dalam bentuk ln, kemudian diuji normalitas residunya kembali dan ternyata residu terdistribusi normal. Tabel berikut ringkasan uji normalitas dari 2 model, dimana model 1 menggunakan variabel dependent jumlah pendaftar dan model 2 menggunakan variabel dependent $\ln$ jumlah

Tabel 9. Hasil Uji Normalita Residu

\begin{tabular}{|c|l|c|c|}
\hline Model & Variabel Dependen & Asymp. Sig. (2-tailed) & Kesimpulan \\
\hline Model 1 & Jumlah Pendaftar & .005 & Tidak Normal \\
\hline Model 2 & Ln Jumlah Pendaftar & .754 & Normal \\
\hline
\end{tabular}

Uji overall melalui uji anova didapatkan nilai $P_{\text {value }}$ kedua model kurang dari $5 \%$. Hal ini berarti variabel akreditasi, status mutu, status sekolah, jenis sekolah dan lokasi berpengaruh terhadap ln jumlah pendaftar sekolah SMA dan MA di Sumenep pada tingkat signifikansi 5\%. Tabel berikut merupakan ringkasan hasil uji anova.

Tabel 10. Hasil Uji Anova

\begin{tabular}{|r|l|c|c|c|}
\hline Model & Variabel Dependen & F & Sig. & Kesimpulan \\
\hline Model 1 & Jumlah Pendaftar & 18.128 & $.000^{\mathrm{a}}$ & Berpengaruh \\
\hline Model 2 & Ln Jumlah Pendaftar & 14.488 & $.000^{\mathrm{a}}$ & Berpengaruh \\
\hline
\end{tabular}

Uji individu melalui uji $t$ didapatkan nilai $\mathrm{P}_{\text {value }}$ kurang dari 5\% untuk variabel status mutu, status sekolah dan lokasi pada model 1. Hal ini berarti bahwa variabel status mutu, status sekolah dan lokasi berpengaruh terhadap jumlah pendaftar SMA dan MA di Sumenep pada tingkat signifikansi 5\%. Untuk model 2, variabel akreditasi dan status sekolah yang berpengaruh terhadap $\ln$ jumlah pendaftar. Tabel berikut ringkasan uji $\mathrm{t}$ hasil perhitungan dari SPSS 16

Tabel 11. Hasil Uji t

\begin{tabular}{|l|c|c|l|c|c|l|}
\hline \multirow{2}{*}{\multicolumn{1}{c|}{ Variabel }} & \multicolumn{4}{c|}{ Model 1 } & \multicolumn{3}{c|}{ Model 2 } \\
\cline { 2 - 7 } & $\mathbf{t}$ & Sig. & \multicolumn{1}{c|}{ Kesimpulan } & t & Sig. & Kesimpulan \\
\hline D_Akreditasi_A & 4.775 & .000 & Berpengaruh & 5.724 & .000 & Berpengaruh \\
\hline D_Akreditasi_B & 1.972 & .052 & Tidak berpengaruh & 4.711 & .000 & Berpengaruh \\
\hline D_Akreditasi_C & -.045 & .964 & Tidak berpengaruh & 1.442 & .153 & Tidak berpengaruh \\
\hline
\end{tabular}




\begin{tabular}{|l|r|r|l|r|r|l|}
\hline D_Mutu_SPM & 2.937 & .004 & Berpengaruh & .789 & .432 & Tidak berpengaruh \\
\hline D_Mutu_PraSSN & 2.719 & .008 & Berpengaruh & .753 & .453 & Tidak berpengaruh \\
\hline D_Mutu_SSN & 2.890 & .005 & Berpengaruh & 1.067 & .289 & Tidak berpengaruh \\
\hline D_Status_Swasta & -6.484 & .000 & Berpengaruh & -3.480 & .001 & Berpengaruh \\
\hline D_jenis & 1.511 & .134 & Tidak berpengaruh & -.111 & .912 & Tidak berpengaruh \\
\hline D_pinggiran & -3.785 & .000 & Berpengaruh & -1.066 & .289 & Tidak berpengaruh \\
\hline D_pesisir & -4.118 & .000 & Berpengaruh & -1.176 & .243 & Tidak berpengaruh \\
\hline
\end{tabular}

Melalui nilai $\mathrm{R}^{2}$ dan $\mathrm{R}_{\text {adjusted }}^{2}$ dari beberapa model akan ditentukan model yang terbaik. Diawali dari model dengan variabel independen yang berpengaruh, yaitu status sekolah, dilanjutkan akreditasi, status mutu dan yang terakhir lokasi. Variabel jenis sekolah tidak dimasukkan karena dari model 1 dan model $2 \mathrm{di}$ atas tidak berpengaruh terhadap variabel dependen. Variabel dependen menggunakan $\ln$ jumlah pendaftar. Tabel berikut ringkasan dari perhitungan dengan menggunakan SPSS 16.0

Tabel 12. Nilai $\mathrm{R}^{2}$ dan ${ }_{\text {adjusted }} \mathrm{R}^{2}$

\begin{tabular}{|l|l|c|r|}
\hline \multicolumn{1}{|c|}{ Model } & \multicolumn{1}{|c|}{ Variabel Independen } & $\mathbf{R}^{\mathbf{2}}$ & adjusted $\mathbf{R}^{\mathbf{2}}$ \\
\hline Model A & status sekolah & 0,346 & 0,340 \\
\hline Model B & status sekolah dan akreditasi & 0,601 & 0,584 \\
\hline Model C & $\begin{array}{l}\text { status sekolah, akreditasi dan status } \\
\text { mutu }\end{array}$ & 0,608 & 0,579 \\
\hline Model D & $\begin{array}{l}\text { status sekolah, akreditasi, status mutu } \\
\text { dan lokasi }\end{array}$ & 0,614 & 0,576 \\
\hline
\end{tabular}

Pada tabel di atas tampak bahwa penambahan nilai $\mathrm{R}_{\text {adjusted pada model } \mathrm{B}}$ terjadi peningkatan yang banyak, sedangkan pada model $\mathrm{C}$ dan model $\mathrm{D}$ mengalami penurunan. Untuk itulah model selanjutnya hanya menggunakan 2 variabel yaitu akreditas dan status sekolah dengan variabel dependennya ln jumlah pendaftar.

\section{Pengujian Asumsi Klasik}

a). Uji Normalitas Residual

Hasil perhitungan untuk pengujian normalitas adalah sebagai berikut :

Tabel 13. Hasil Pengujian Normalitas

\begin{tabular}{|c|c|c|}
\hline Model & Asymp. Sig. (2-tailed) & Kesimpulan \\
\hline Model B & .609 & Normal \\
\hline
\end{tabular}

Berdasarkan tabel di atas dapat diketahui bahwa nilai statistik Kolmogorov-Smirnov yang diperoleh mempunyai taraf signifikan yang lebih besar dari 0.05 yaitu 0.609 hal ini membuktikan bahwa residual berdistribusi normal, yang berarti bahwa asumsi kenormalan residunya terpenuhi.

b). Heteroskedastisitas

Hasil regresi fungsi-fungsi residual pada model $\mathrm{B}$ diringkas pada tabel berikut :

Tabel 14. Hasil Uji Heteroskedastisitas

\begin{tabular}{|l|r|r|l|}
\hline \multicolumn{1}{|c|}{ Variabel } & \multicolumn{1}{c|}{ t } & \multicolumn{1}{c|}{ Sig. } & Kesimpulan \\
\hline D_Status_Swasta & -.005 & .996 & Tidak Berpengaruh \\
\hline D_Akreditasi_A & -.416 & .679 & Tidak Berpengaruh \\
\hline D_Akreditasi_B & .240 & .811 & Tidak Berpengaruh \\
\hline D_Akreditasi_C & -.379 & .705 & Tidak Berpengaruh \\
\hline
\end{tabular}


Pada tabel di atas tampak bahwa semua variabel independen tidak berpengaruh signifikan terhadap mutlak residu. Maka model B tidak mengandung masalah heteroskedastisitas.

c). Autokorelasi

Nilai Durbin_watson diperoleh hasil dari model adalah 2,005. Dari tabel statistik Durbin-warson dengan jumlah variabel independen $4(\mathrm{k}=4)$ dan jumlah sampel $102(\mathrm{n}=102)$, didapatkan $\mathrm{dl}=$ 1,592 dan $\mathrm{du}=1,758$. Maka nilai DW model B berada posisi nomor 3 berdasarkan kriteria keputusan pada tabel 4 , sehingga disimpulkan tidak terjadi autokorelasi.

d). Multikolinieritas

Dari hasil pengujian terhadap gejala mulitikolinieritas diperoleh hasil sebagai berikut

Tabel 15. Hasil Uji Multikolinieritas

\begin{tabular}{|l|r|r|}
\hline \multirow{2}{*}{ Model B } & \multicolumn{2}{|c|}{ Collinearity Statistics } \\
\cline { 2 - 3 } & Tolerance & \multicolumn{1}{c|}{ VIF } \\
\hline D_Status_Swasta & .722 & 1.384 \\
\hline D_Akreditasi_A & .632 & 1.583 \\
\hline D_Akreditasi_B & .679 & 1.473 \\
\hline D_Akreditasi_C & .703 & 1.422 \\
\hline
\end{tabular}

Berdasarkan hasil pengujian dapat diketahui bahwa nilai VIF seluruh variabel bebas dalam penelitian ini kurang dari 10. Artinya pada penelitian ini tidak terjadi gejala multikolinier.

Setelah semua asumsi klasik terpenuhi, maka dilanjutkan dengan meregresikan untuk mendapatkan dugaan nilai parameter.

\section{Uji Model Regresi \\ a). Uji $F$}

Hasil output SPSS 16 untuk uji overall adalah sebagai berikut :

Tabel 16. Hasil Uji F

\begin{tabular}{|c|c|c|c|c|r|}
\hline Model & Variabel Dependen & $\mathbf{F}$ & Sig. & $\mathbf{R}^{\mathbf{2}}$ & adjusted $^{\mathbf{2}}$ \\
\hline Model B & Ln Jumlah Pendaftar & 36.481 & $.000^{\mathrm{a}}$ & .601 & .584 \\
\hline
\end{tabular}

Pada tabel di atas tampak bahwa nilai $p$-value kurang dari 0,05 yaitu 0,000 maka diputuskan tolak $\mathrm{H}_{0}$ yang berarti bahwa model regresi signifikan atau variabel dummy akreditasi dan status sekolah berpengaruh secara simultan terhadap ln jumlah pendaftar.

Untuk melihat variabilitas ln jumlah pendaftar yang mampu dijelaskan oleh variabilitas ln akreditasi dan status sekolah dapat dilihat dari nilai $\mathrm{R}^{2}$. Pada tabel di atas tampak bahwa nilai $\mathrm{R}^{2}=$ 0,601 yang artinya variabilitas $\ln$ jumlah pendaftar yang mampu dijelaskan oleh variabilitas akreditasi dan status sekolah adalah $60,1 \%$ sisanya $39,9 \%$ dijelaskan oleh faktor lain selainnya.

b). Uji t

Hasil perhitungan terkait uji individu dengan SPSS 16.0 diringkas pada tabel berikut :

Tabel 17. Hasil Uji t

\begin{tabular}{|l|r|r|r|l|}
\hline \multicolumn{1}{|c|}{ Variabel } & \multicolumn{1}{c|}{ B } & \multicolumn{1}{c|}{ t } & \multicolumn{1}{c|}{ Sig. } & \multicolumn{1}{c|}{ Kesimpulan } \\
\hline D_Status_Swasta & -.911 & -3.967 & .000 & Berpengaruh \\
\hline D_Akreditasi_A & 1.610 & 6.870 & .000 & Berpengaruh \\
\hline D_Akreditasi_B & .862 & 5.727 & .000 & Berpengaruh \\
\hline D_Akreditasi_C & .243 & 1.733 & .086 & Tidak Berpengaruh \\
\hline
\end{tabular}


Dari tabel di atas dapat disimpulkan bahwa status sekolah, akreditasi A dan akreditasi B berpengaruh signifikan terhadap ln jumlah pendaftar. Status sekolah yang negeri lebih diminati 91,1\% lebih tinggi dari pada status sekolah swasta. Sekolah dengan akreditasi A lebih diminati 161\% kali dibandingkan sekolah yang belum terakreditasi. Sekolah dengan akreditasi B lebih diminati 86,2\% kali dibandingkan sekolah yang tidak terakreditasi. Sementara sekolah akreditasi $\mathrm{C}$ tidak bisa dibandingkan karena tidak berpengaruh signifikan.

\section{Uji Anova One Way dan Kruskal Wallis}

Untuk mengetahui adakah perbedaan jumlah pendaftar antara kelompok sekolaha negeri akreditasi A, negeri akreditasi B, swasta akreditasi A, swasta akreditasi B, swasta akreditasi C dan swasta tidak terakreditasi digunakan uji anova one way jika persyaratan data terdistribusi normal terpenuhi. Hasil uji normalitas mengunakan kolmogorovSmirnov test sebagai berikut :

Tabel 18. Hasil Uji Normalitas

\begin{tabular}{|l|r|c|}
\hline \multicolumn{1}{|c|}{ Status Sekolah } & Asymp. Sig. (2-tailed) & Kesimpulan \\
\hline Negeri AkreditasiA & .002 & Tidak Normal \\
\hline Negeri Akreditasi B & .000 & Tidak Normal \\
\hline Swasta Akreditasi A & .000 & Tidak Normal \\
\hline Swasta Akreditasi B & .000 & Tidak Normal \\
\hline Swasta Akreditasi C & .077 & Normal \\
\hline Swasta Tidakt Terakreditasi & $.200^{*}$ & Normal \\
\hline
\end{tabular}

Dari tabel di atas sebagian besar tidak terdistribusi normal, maka untuk menguji perbedaan rata-rata antar dua sekolah menggunakan uji Kruskal Wallis. Hasil perhitungan diringkas pada tabel berikut

Tabel 19. Hasil Uji Kruskal-Wallis

\begin{tabular}{|l|r|r|}
\hline \multicolumn{1}{|c|}{ Status Sekolah } & \multicolumn{1}{c|}{ Jumlah Sekolah } & \multicolumn{1}{c|}{ Mean Rank } \\
\hline Negeri AkreditasiA & 5 & 32.80 \\
\hline Negeri Akreditasi B & 4 & 27.50 \\
\hline Swasta Akreditasi A & 2 & 17.75 \\
\hline Swasta Akreditasi B & 14 & 18.29 \\
\hline Swasta Akreditasi C & 7 & 16.14 \\
\hline Swasta Tidakt Terakreditasi & 6 & 10.42 \\
\hline Sig. = 0,015 & \multicolumn{2}{|l}{} \\
\hline
\end{tabular}

Dari tabel di atas dapat disimpulkan bahwa setidaknya terdapat 2 sekolah yang mempunyai rata-rata jumlah pendaftar yang berbeda. Urutan rata-rata jumlah pendaftar mulai tertinggi adalah sekolah negeri akreditasi A, negeri akreditasi B, swasta akreditasi A, swasta akreditasi B, swasta akreditasi C dan swasta tidak terakreditasi.

\section{Analisis Crostabing}

Deskripsi banyaknya sekolah SMA/MA di Kabupaten Sumenep menurut status, akreditasi dan lokasi tampak pada gambar 1. Urutan jumlah sekolah mulai terbanyak adalah sekolah swasta akreditasi C, swasta tidak akreditasi, swasta akreditasi B, swasta akreditasi A, negeri akreditasi B dan yang paling sedikit jumlahnya adalah sekolah negeri akreditasi A. Sekolah SMA/MA di 
Kabupaten Sumnep terbanyak berada di daerah pinggiran selanjutnya di pesisir

dan yang paling sedikit di kota.

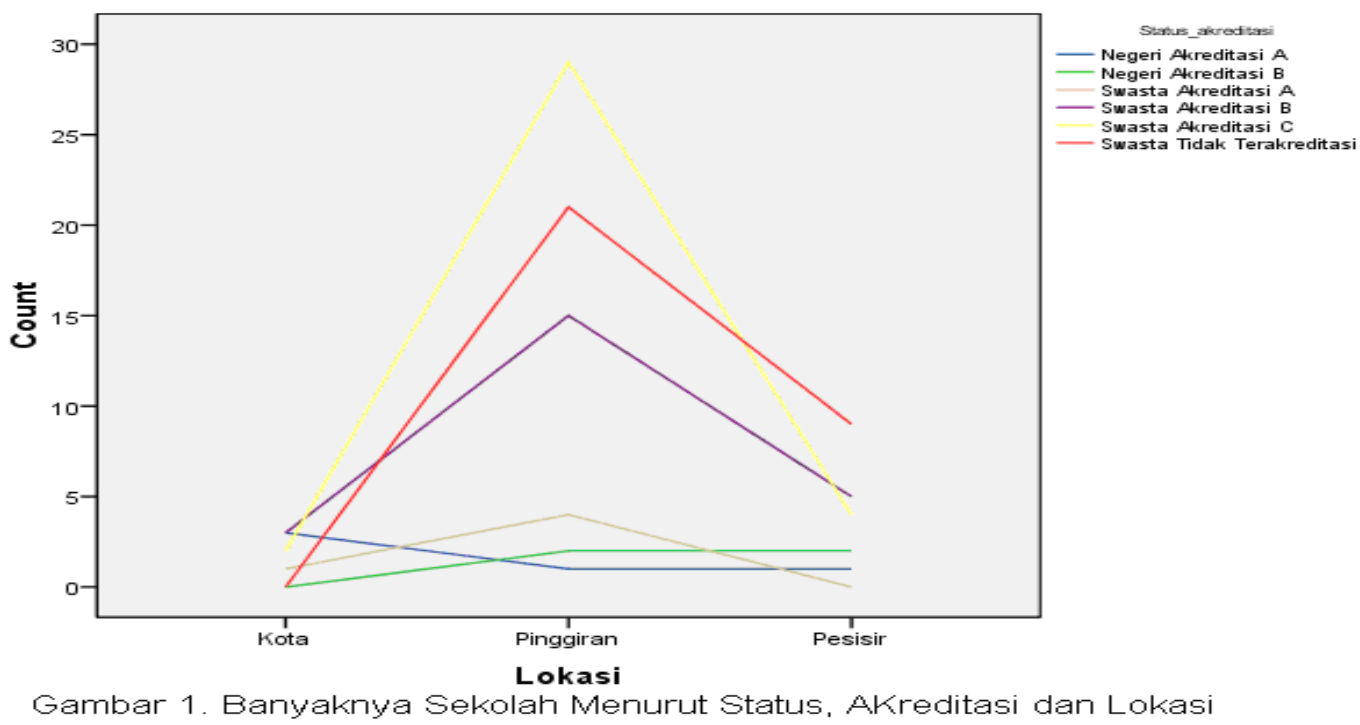

Deskripsi rata-rata jumlah jumlah pendaftar sekolah SMA/MA tahun pendaftar menurut status sekolah, akreditasi dan lokasi tampak pada gambar 2011 terbanyak di lokasi kota, dilanjutkan 2. Secara umum urutan peminat atau

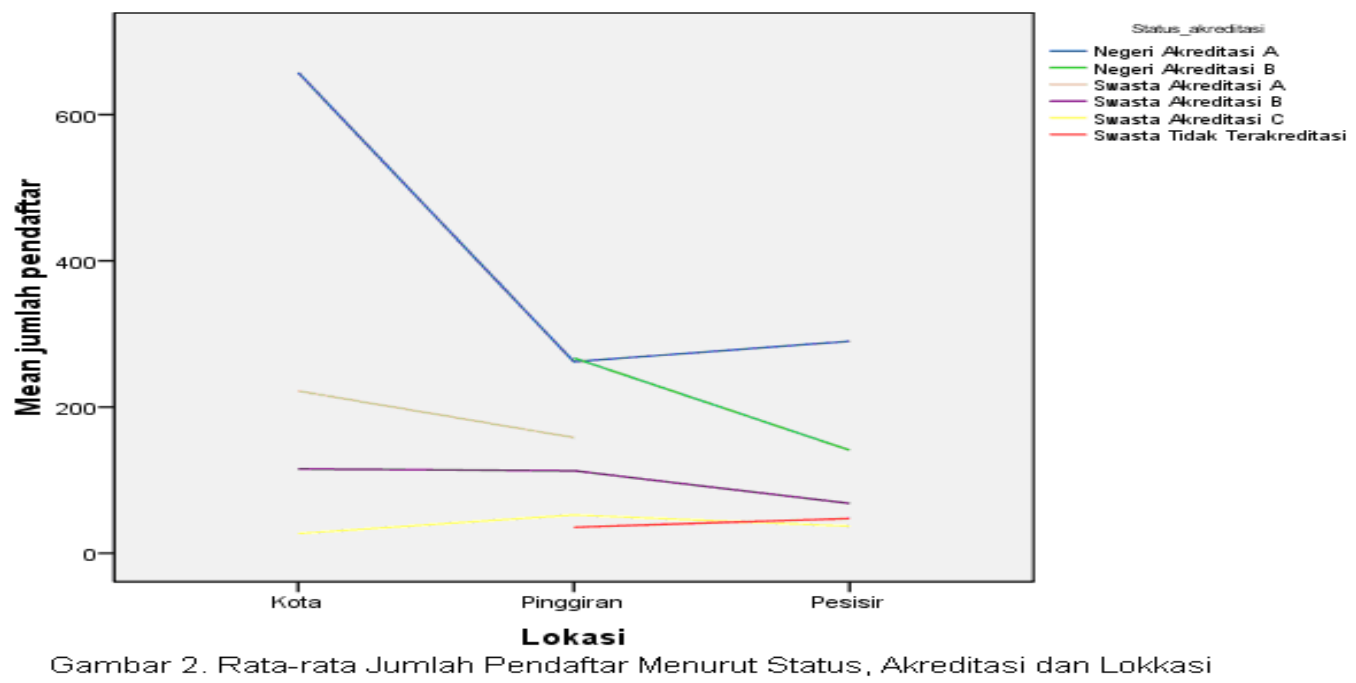

Urutan peminat SMA/MA di kota adalah sekolah negeri akreditasi A, swasta akreditasi A, swasta akreditasi B dan swasta akreditasi C. Urutan peminat SMA/MA di pinggiran adalah sekolah negeri akreditasi B, negeri akreditasi A, swasta akreditasi A, swasta akreditasi B, swasta akreditasi $\mathrm{C}$ dan yang terakhir swasta tidak terakreditasi. Sementara itu, urutan peminat SMA/MA di daerah pesisir adalah sekolah negeri akreditasi A, negeri akreditasi B, swasta akreditasi B, swasta tidak terakreditasi dan yang terakhir swasta akreditasi C.

\section{PEMBAHASAN}

Dari hasil perhitungan statistik, model regresi pertama menjelaskan bahwa variabel status mutu, jenis sekolah dan lokasi sekolah tidak berpengaruh terhadap jumlah pendaftar. Tidak berpengaruhnya status mutu, hal ini menunjukkan bahwa 
masyarakat Sumenep dalam memilih sekolah SMA atau MA tidak mempertimbangkan status mutu apakah sekolah berstatus mutu SPM, praSSN, SSN ataukah RSBI. Dari data yang ada bahkan diketahui bahwa sekolah RSBI yang berstatus negeri akreditasi A jumlah pendaftarnya lebih sedikit dibandingkan sekolah lainnya bestatus negeri akreditasi A yang SSN.

Dari perhitungan statistik, jenis sekolah SMA atau MA tidak berpengaruh terhadap jumlah pendaftar. Hal ini berarti jenis sekolah tidak menjadi pertimbangan masyarakat Sumenep dalam memilih sekolah, diduga karena ada anggapan masyarakat bahwa kedua jenis sekolah tersebut adalah sama. Akan tetapi data menunjukkan bahwa rata-rata pendaftar sekolah SMA masih relatif lebih banyak dari pada pendaftar MA, sementara jumlah sekolah jenis SMA lebih sedikit dibandingkan sekolah MA. Menurut data tahun 2011 jumlah sekolah agama dua kali dibanding jumlah sekolah umum, tetapi rata-rata jumlah pendaftar setengah kalinya.

Variabel lokasi juga tidak berpengaruh terhadap jumlah pendaftar SMA/MA. Akan tetapi secara kuantitatif jumlah pendaftar sekolah SMA/MA di kota relatif lebih banyak daripada sekolah yang berlokasi di pinggiran ataupun pesisir.

Variabel status sekolah berpengaruh terhadap jumlah pendaftar sekolah SMA atau MA. Jumlah pendaftar sekolah dengan status negeri 91,1\% lebih banyak daripada sekolah denagn status swasta. Dengan kata lain masyarkat Sumenep mengukur mutu sekolah berdasarkan status sekolah. Status sekolah SMA/MA di Kabupaten Sumenep mempunyai perbandingan yang sangat ekstrim. Perbandingan banyaknya sekolah negeri dengan sekolah swasta $1: 10,4$. Akan tetapi perbandingan rata-rata pendaftarnya $5,4: 1$. Hal ini berarti satu sekolah negeri diperebutkan oleh 28 siswa, sementara kondisi sekolah swasta, satu siswa diperebutkan oleh dua sekolah swasta.

Variabel lain yang berpengaruh terhadap jumlah pendaftar adalah akreditasi. Jumlah pendaftar sekolah dengan akreditasi A 161\% lebih banyka dibandingkan sekolah yang belum terakreditasi. Jumlah pendaftar sekolah dengan akreditasi B 86,2\% lenih banyak daripada sekolah yang tidak terakreditasi. Sementara sekolah akreditasi $\mathrm{C}$ tidak bisa dibandingkan karena tidak berpengaruh secara signifikan.

Menurut hasil uji Kruskal Wallis, urutan sekolah yang mempunyai rata-rata jumlah pendaftar tertinggi hingga terendah adalah sekolah negeri akreditasi A, negeri akreditasi B, swasta akreditasi A, swasta akreditasi B, swasta akreditasi $\mathrm{C}$ dan swasta tidak terakreditasi.

Dari hasil analisis crosstabing, menggambarkan bahwa kualitas sekolah SMA/MA di Kabupaten Sumenep belum merata. Karena sekolah dengan kualitas baik berlokasi di kota dengan jumlah sekolah yang sangat sedikit dibandingkan sekolah di pinggiran dan pesisir dengan jumlah sekolah banyak tapi kualitas kurang baik.

Menurut urutan jumlah peminat sekolah SMA/MA di bagian kota menggambarkan bahwa masyarakat Kota Sumenep memprioritaskan sekolah dengan kualitas yang baik, hal ini ditunjukkan oleh urutan rata-rata jumlah peminat sekolah mulai dari yang bermutu hingga yang kurang bermutu. Urutan peminat sekolah SMA/MA di bagian kota adalah sekolah negeri akreditasi A, swasta akreditasi A, swasta akreditasi B kemudian swasta akreditasi C. Di bagian kota tidak terdapat sekolah negeri akreditasi B dan sekolah tidak terakreditasi. Akan tetapi jumlah pendaftar sekolah SMA/MA dengan lokasi kota jumlahnya jauh lebih banyak dibandingkan di pinggiran dan di pesisir.

$$
\text { Lokasi pinggiran jumlah }
$$
peminatnya terbanyak mulai sekolah negeri akreditasi $\mathrm{B}$, negeri akreditasi $\mathrm{A}$, 
swasta akreditasi A, swasta akreditasi B, swasta akreditasi $\mathrm{C}$, dan yang terakhir swasta tidak terakreditasi. Urutan ini agak ganjil karena rata-rata jumlah pendaftar sekolah negeri akreditasi B lebih banyak dari sekolah negeri akreditasi A. Sekolah negeri akreditasi A di pinggiran hanya satu, yaitu SMAN 1 Ambuten. Sekolah negeri akreditasi B di pinggiran ada dua, yaitu SMAN 1 Bluto dan SMAN 1 Gapura. Diantara ketiga sekolah itu, jumlah pendaftar paling banyak SMAN 1 Bluto, hal ini disebabkan di daerah Bluto relatif lebih sedikit sekolah pilihan lainnya (SMA swasta ataupun MA swasta) dibandingkan di daerah Gapura dan Ambuten. Sehingga masyarakat di daerah Bluto dan sekitarnya memiliki sedikit alternatif pilihan sekolah. Hanya SMAN 1 Bluto rujukan sekolah bermutu pertama dan utama. Secara umum jumlah pendaftar di daerah pinggiran masih relatif lebih banyak dibandingkan di daerah pesisir.

Urutan jumlah pendaftar untuk lokasi pesisir adalah sekolah negeri akreditasi A, negeri akreditasi B, swasta akreditasi B, swasta tidak terakreditasi dan swasta akreditasi C. Jumlah sekolah swasta tidak terakreditasi sebanyak 9, terdiri dari 2 SMA swasta dan 7 MA swasta. Sedangkan sekolah swasta akreditasi C sebanyak 4 sekolah MA. Jumlah pendaftar untuk sekolah swasta tidak terakreditasi lebih banyak dibandingkan sekolah swasta akreditasi C. Hal ini disebabkan ada kecenderungan masyarakat pesisir jika tidak diterima di sekolah negeri maka akan memilih sekolah agama yang dekat dengan rumah meskipun tidak terakreditasi. Jumlah pendaftar di pesisir paling sedikit dibandingkan dengan di kota dan di pinggiran.

Dengan membandingkan antara jumlah pendaftar dan banyaknya sekolah menggambarkan persaingan yang ketat bagis siswa untuk pendaftar sekolah akreditasi A dan terjadi persaingan yang ketat untuk mendapatkan siswa untuk sekolah-sekolah yang belum terakreditasi atau akreditasi C. Hal ini menandakan adanya gejala disparitas kesempatan dalam memperoleh pendidikan yang bermutu. Perbandingan antara jumlah pendaftar dan banyaknya sekolah antar lokasi akan sedikit memberikan gambaran terkait dengan disparitas pendidikan di Kabupaten Sumenep. Di bagian kota jumlah sekolah paling sedikit, mempunyai mutu bagus tetapi jumlah pendaftar paling banyak dibandingkan lokasi lainnya. Hal ini bertolak belakang dengan kondisi di pinggiran dan di pesisir, dimana jumlah sekolah sangat banyak dengan status mutu yang standard dan bahkan kurang bagus, tetapi jumlah pendaftarnya jauh lebih sedikit dengan jumlah pendaftar di kota. Hal ini menandakan adanya gejala disparitas memperoleh kesempatan pendidikan yang tidak sama diantara berbagai tempat kota, pinggiran dan pesisir.

\section{KESIMPULAN}

1. Hasil analisis regresi dummy didapatkan, yang berpengaruh terhadap jumlah pendaftar adalah status sekolah dan akreditasi. Status sekolah negeri lebih diminati $91,1 \%$ lebih tinggi dari pada status sekolah swasta. Sekolah dengan akreditasi A lebih diminati $161 \%$ kali dibandingkan sekolah yang belum terakreditasi. Sekolah dengan akreditasi B lebih diminati 86,2\% kali dibandingkan sekolah yang tidak terakreditasi.

2. Urutan jumlah pendaftar SMA/MA di kota adalah sekolah negeri akreditasi A, swasta akreditasi A, swasta akreditasi B dan swasta akreditasi C. Urutan peminat SMA/MA di pinggiran adalah sekolah negeri akreditasi B, negeri akreditasi $\mathrm{A}$, swasta akreditasi A, swasta akreditasi B, swasta akreditasi $\mathrm{C}$ dan yang terakhir swasta tidak terakreditasi. Sementara itu, urutan peminat SMA/MA di daerah pesisir adalah sekolah negeri akreditasi
A, negeri akreditasi B, swasta 
akreditasi B, swasta tidak terakreditasi dan yang terakhir swasta akreditasi C.

3. Terdapat gejala disparitas dalam memperoleh kesempatan pendidikan yang bermutu untuk lokasi kota, pinggiran dan pesisir. Karena jumlah sekolah bermutu dan rata-rata jumlah pendaftar lebih banyak di kota dibandingkan di pinggiran maupun di pesisir.

\section{DAFTAR PUSTAKA}

Peningkatan Mutur Berbasis
Sekolah: Buku 1. Jakarta: Dirjen
Dikdasmen Depdiknas RI
2003. Undang Undang

Sisdiknas 2003. Jakarta: Redaksi Sinar Grafika 2006. Peraturan Pemerintah RI. Nomor 19 tahun 2005 tentang Standar Nasional Pendidikan. Jakarta: PT. Binatama Rata . 2010. Pedoman Sekolah Standar Nasional. Jakarta: Dirjen MPDM Kemendiknas RS

Biro Pusat Statistik Kab. Sumenep. 2011. Sumenep Dalam Angka: Laporan data tahunan 2011 tidak diterbitkan.

Ghozali, I. 2006. Aplikasi Analisis Multivariate dengan Program SPSS. Penerbit Universitas Diponegoro. Semarang

Hudgins, Bryce B, etc.. 1983. Educational Psychology. Itasca Illinois: FE. Peacock Publisher, Inc.

Nasution, S. 1999. Sosiologi Pendidikan. Jakarta: PT. Bumi Aksara

Santrock, John W. 2010. Psikologi Pendidikan Ed. 2. Jakarta: Kencana

Widarjono, A. 2010. Analisis Statistika Multivariat Terapan. Pnerbit UPP STIM YKNP. Yogyakarta. 